\title{
Helicobacter pylori Lipopolysaccharide Hinders Polymorphonuclear Leucocyte Apoptosis
}

\author{
Véronique Hofman, Vittorio Ricci, Baharia Mograbi, Patrick Brest, Frédéric Luciano, \\ Patrice Boquet, Bernard Rossi, Patrick Auberger, and Paul Hofman
}

Laboratoire d'Anatomie-Pathologique (VH, PH), INSERM 452 (VR, PBo), INSERM 364 (BM, PBr, BR, PH), and INSERM 526 (FL, PA), Faculté de Médecine, Nice, France

\begin{abstract}
SUMMARY: A prominent histologic feature of Helicobacter pylori infection is a dense infiltration of polymorphonuclear leukocytes (PMNL) in gastric mucosa. H. pylori lipopolysaccharide (LPS) has been recognized as a primary virulence factor evoking acute mucosal inflammatory reaction. Previous works have shown that $H$. pylori LPS immunologic activities are lower than those of enterobacterial LPS. However, the effect of $H$. pylori LPS on spontaneous PMNL apoptosis, and mechanisms by which this $H$. pylori LPS may promote PMNL survival remain to be established. In this study, we investigated, by both morphologic and biochemical approaches, the action of $H$. pylori LPS on PMNL apoptosis in vitro, using broth culture filtrates (BCF) of $H$. pylori strains with different genotypes. We found that BCF from $H$. pylori caused a significant delay in spontaneous PMNL apoptosis and this delay was independent of the VacA, cag pathogenicity island and urease status. We demonstrated that LPS in BCF is responsible for this effect because it was abrogated by the LPS antagonist B287 (a synthetic analog of Rhodobacter sphaeroides lipid A). Moreover, BCF from H. pylori induced P42/44 MAP kinase activation in PMNL. Similar results were obtained with BCF of an Escherichia coli strain. Taken together these data suggest that longer survival of PMNL induced by $H$. pylori LPS may increase gastric epithelium injury in $H$. pylori-associated diseases. (Lab Invest 2001, 81:375-384).
\end{abstract}

$H$ elicobacter pylori infection elicits an inflammatory cell response, and the severity of epithelial injury appears to be directly correlated with the extent of polymorphonuclear leukocyte (PMNL) infiltration (Davies et al, 1994; Mizuki et al, 2000). The severity of phagocyte recruitment is mainly associated with virulent type I strains of $H$. pylori that secrete a cytotoxin (VacA) and contain the cag pathogenicity island (PAI) (Blaser, 1997; Censini et al, 1996; Covacci et al, 1999; Labigne and de Reuse, 1996). Recruitment of PMNL is mediated by secretion of epithelial interleukin 8 (IL-8) induced by adherence of $H$. pylori at the apical side of epithelial cells (Crabtree et al, 1995; Hofman et al, 2000). It is thought that both bacterial components and host inflammatory mediators contribute to the subsequent tissue damage. More particularly, excess reactive oxygen metabolite production by $P M N L$ has a pathogenic role in $H$. pylori-related gastroduodenal disease (Davies et al, 1994).

$H$. pylori is a noninvasive bacteria, but several bacterial products can enter the extracellular space and be in contact with PMNL in the lamina propria (Cao et al, 1998; Evans et al, 1995; Fiocca et al, 1999; Keenan et al, 1999; Mai et al, 1991, 1992; Schraw et al, 1999). The effects of bacterial products secreted by $H$. pylori or released after bacteria autolysis on the differ-

Received November 13, 2000.

Address reprint requests to: Dr. Paul Hofman, INSERM Unité 364, Faculté de Médecine, avenue de Valombrose, 06107 Nice, Cédex 02, France.E-mail:hofman@unice.fr ent functions of phagocytes (such as radical oxygen intermediates production, chemotaxis, phagocytosis, CD11b regulation) have been extensively studied (Akyon and Hascelik, 1999; Hansen et al, 1999a, 1999b; Harris et al, 1996; Mayo et al, 1997; Suzuki et al, 1992; Zhang et al, 1996). Among these products, lipopolysaccharides (LPS) may modulate the PMNL behavior. However, low immunologic activities of $H$. pylori LPS have been previously reported as compared with those of different bacterial LPS such as enterobacterial LPS (Muotiala et al, 1992; Nielsen et al, 1994). Interestingly, by inducing a low immunologic response, LPS may prolong $H$. pylori infection longer than would occur with a more aggressive pathogen (Moran, 1995). It has been suggested that the unusual structure of $H$. pylori lipid A might explain the reduced biologic activity of $H$. pylori LPS compared with other enterobacterial LPS (Geis et al, 1990; Moran, 1995).

Previous studies have demonstrated that PMNL activated with LPS from different enterobacteria or streptococci showed a longer survival compared with untreated PMNL (Colotta et al, 1992). Moreover, PMNL surviving in response to LPS retained their capacity to produce superoxide anion. In addition, prolongation of PMNL survival may be important for the regulation of host resistance and persistence of inflammation (Haslett, 1992; Savill et al, 1989). The effect of $H$. pylori LPS on PMNL survival has not yet been documented. The aim of the present study was to examine the relationship between PMNL survival in relation to LPS and to the genotypes for cag PAI, VacA, and urease. 


\section{Results}

\section{Morphologic Study}

Morphologic evaluation of PMNL cultured for 24 hours at $37^{\circ} \mathrm{C}$ revealed a statistically significant $(p<0.01)$ decrease in spontaneous PMNL apoptosis by the different broth culture filtrates (BCF) of $H$. pylori. By light microscopy, control PMNL showed a proportion of $5 \% \pm 2 \%$ apoptotic cells after 2 hours of incubation (Fig. $1 \mathrm{~A}$ ) and $92 \% \pm 8 \%$ apoptotic cells after 24 hours (Fig. 1B). PMNL incubated with BCF of different strains of $H$. pylori showed after 24 hours a reduced number of apoptotic cells $(14 \% \pm 5 \%$ and $16 \% \pm 7 \%$ for 60190 strain and G21 strain, respectively) (Fig. 1, C and D). Using B287 (a synthetic analog of Rhodobacter sphaeroides lipid A), the proportion of apoptotic cells in PMNL treated with BCF from 60190 strain and its isogenic mutants (60190:v1 and 60190:C - strains) and in PMNL treated with BCF from G21 strain were similar to that of control cells after 24 hours: $85 \% \pm 11 \%$ vs $90 \% \pm 6 \%$ vs $82 \% \pm 9 \%$ vs $89 \% \pm 8 \%$ vs $90 \% \pm 8 \%$ for 60190 strain (Fig. $1 \mathrm{E}$ ), 60190:v1 strain (Fig. 1F), 60190:C- strain (Fig. 1G), G21 strain (Fig. $1 \mathrm{H}$ ) and control cells, respectively. Apoptosis was induced similarly by staurosporine treatment in PMNL incubated with BCF from 60190 strain (Fig. 1I) and in control PMNL (Fig. 1J): $95 \% \pm$ $5 \%$ vs $92 \% \pm 8 \%$ for 60190 strain and control cells, respectively.

Evaluation of PMNL apoptosis by the TUNEL (TdTmediated dUTP nick end labeling) method was performed at 12 hours of culture, because this method can detect apoptosis earlier than the Giemsa staining technique. However, using both methods, we obtained similar results; in control cells after a 2-hour culture period only rare apoptotic cells were detected (Fig. 2A), whereas most of control cells after a 12-hour culture revealed nuclear positivity (Fig. 2C). By contrast, only a few positive nuclei could be identified at 12 hours in PMNL treated with BCF from $60190 \mathrm{H}$. Pylori strain (Fig. 2B), G21 H. pylori strain (Fig. 2E), or Escherichia coli 055:B5 strain (Fig. 2F). B287 clearly antagonized the antiapoptotic effect of BCF from 60190 strain after 12 hours of culture (Fig. 2D). These results were also quantified by flow cytometry (means \pm SEM, $n=3$ ): $6 \% \pm 2 \%$ and $81 \% \pm 7 \%$ positive cells were observed after 2 hours and 12 hours of culture in the absence of BCF, respectively. BCF from $60190 \mathrm{H}$. pylori strain, G21 H. pylori strain, and E. coli 055:B5 strain, reduced the number of positive cells to $30 \% \pm$ $5 \%, 28 \% \pm 7 \%$, and $32 \% \pm 6 \%$, respectively, after 12 hours of culture. Finally, B287 was found to block the antiapoptotic effect of BCF from $60190 \mathrm{H}$. pylori strain $(84 \% \pm 6 \%$ positive cells after 12 hours of culture).

\section{DNA Laddering}

As shown in Figure 3, PMNL incubated with culture medium alone (RPMI 1640, 10\% FCS) for 2 hours did not exhibit any increase in DNA laddering in comparison with control PMNL at 0 hours. Similar results were

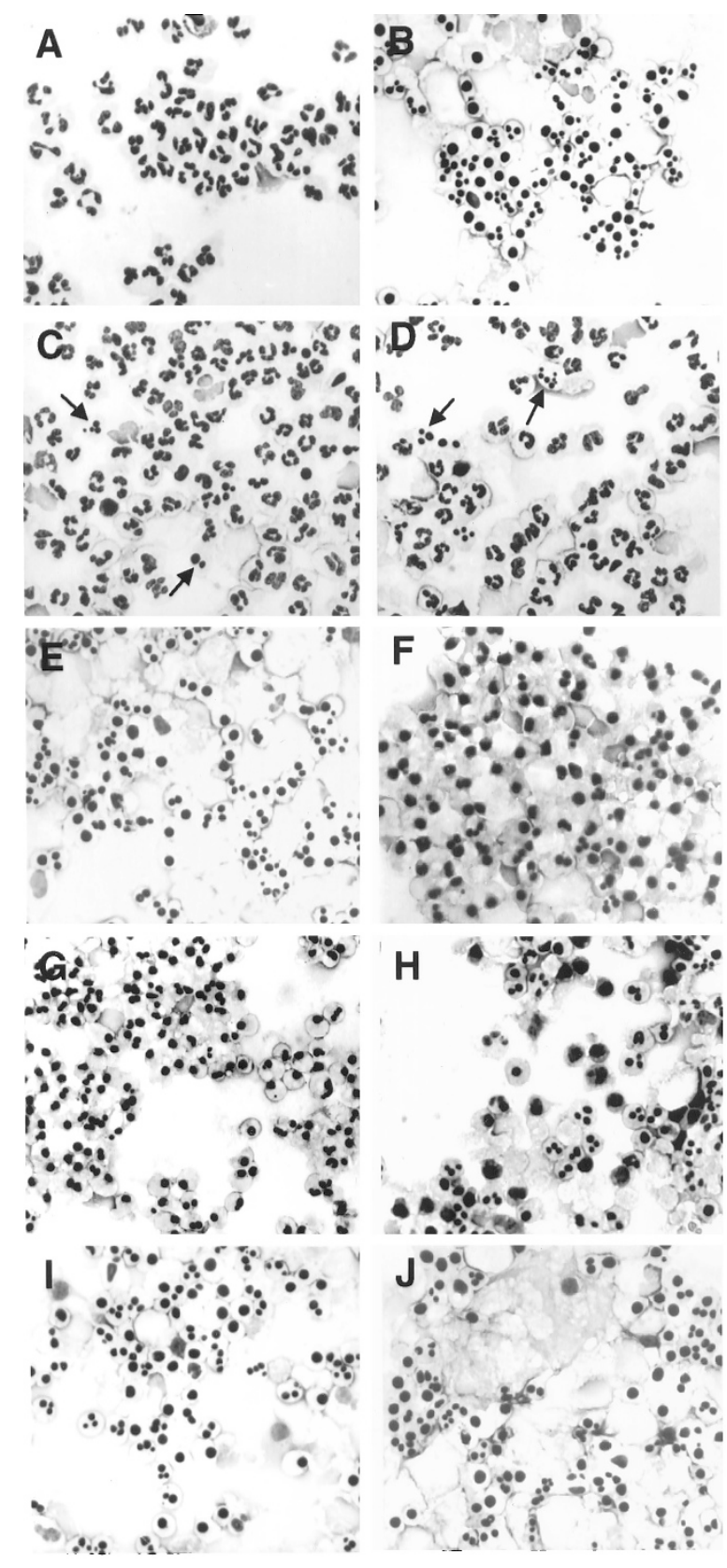

Figure 1.

Analysis of neutrophil apoptosis by morphologic evaluation of cultured PMNL. Control cells ( 2 hours of culture) show absence of apoptotic cells (A), whereas almost all cells at 24 hours of culture revealed nuclear condensation (B). Only a few apoptotic bodies and pyknotic nuclei (arrows) can be identified at 24 hours for the treated polymorphonuclear leukocytes (PMNL) with broth culture filtrate (BCF) from 60190 Helicobacter pylori strain (C) or with BCF from G21 H. pylori strain (D). Using B287, numerous apoptotic cells in PMNL treated with BCF from 60190 strain (E), in PMNL treated with BCF from G21 strain (F), in PMNL treated with BCF from 60190:v1 (G) and in PMNL treated with BCF from 60190:C - strain $(\mathrm{H})$ were noted after 24 hours. All PMNL showed apoptotic features similar to staurosporine-treated cells with (I) or without (J) preincubation with BCF from $60190 \mathrm{H}$. pylori strain.

obtained with PMNL incubated for 2 hours with different BCF from $H$. pylori strains, with LPS from $E$. coli 055:B5, or with culture medium supplemented with 3 $\mathrm{mM} \mathrm{NH} \mathrm{N}_{4} \mathrm{Cl}$. Staurosporine $1 \mu \mathrm{M}$, used as a positive control, strongly induced DNA fragmentation of PMNL. After 24 hours of culture, untreated PMNL 

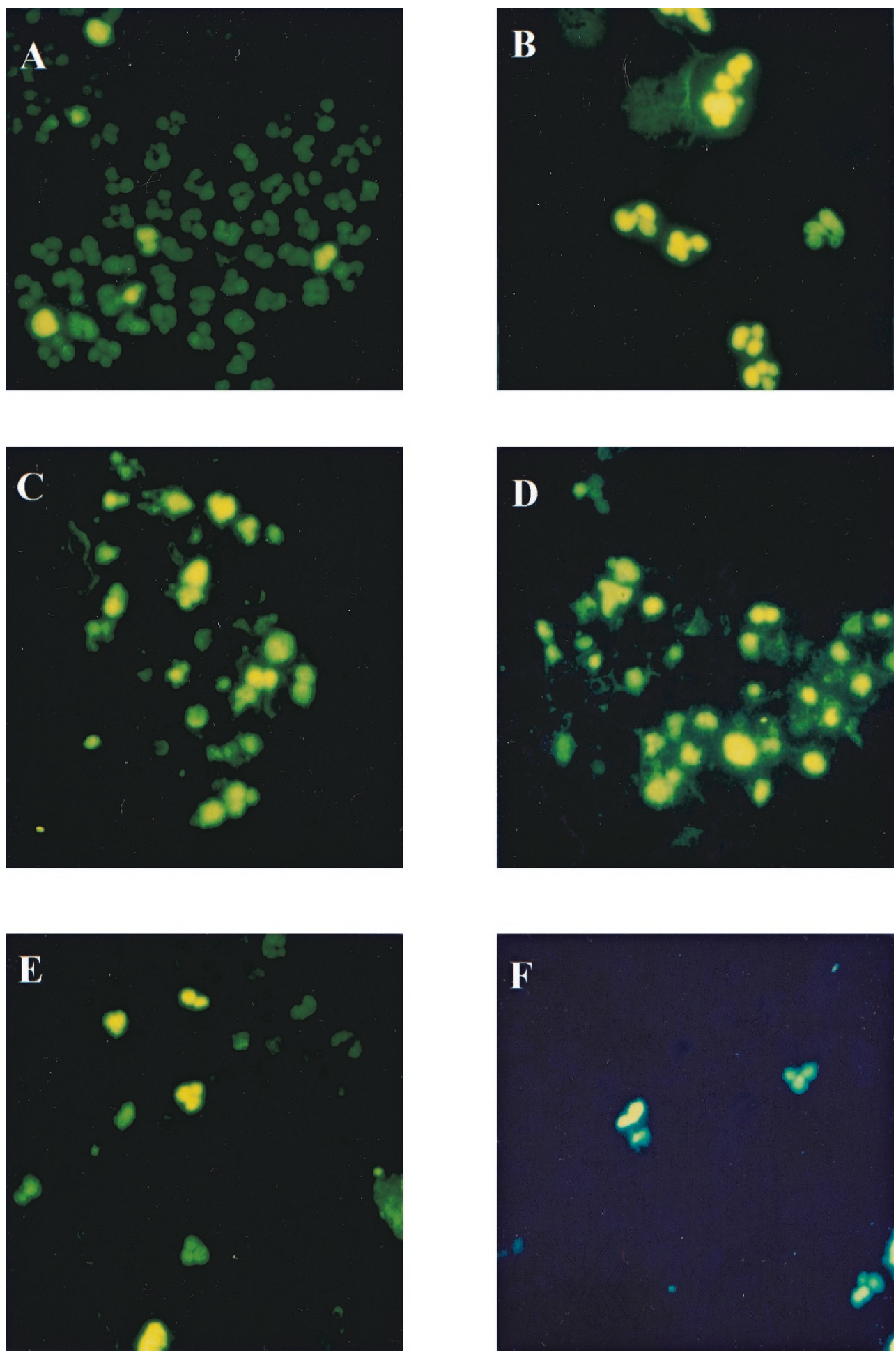

\section{Figure 2.}

Analysis of neutrophil apoptosis by TUNEL (TdT-mediated dUTP nick end labeling) method. A, Control cells at 2 hours of culture show a few apoptotic cells. B, Only a few positive nuclei can be identified at 12 hours in PMNL treated with BCF from $60190 \mathrm{H}$. pylori strain. C, Almost all control cells at 12 hours of culture revealed nuclear positivity. D, Using B287, numerous apoptotic cells in PMNL treated with BCF from 60190 strain were noted at 12 hours. E, Very few positive nuclei were observed at 12 hours in PMNL treated with BCF from G21 H. pylori strain and F, with BCF from Escherichia coli.

showed a significant increase in DNA fragmentation, whereas PMNL incubated for 24 hours with the different BCF of $H$. pylori strains (ie, $60190, \mathrm{G} 21$, strain 4) or with LPS from E. coli 055:B5, exhibited a reduced amount of low molecular weight DNA in comparison with control PMNL (Fig. 3). Finally, BCF from 60190 strain has no effect on staurosporine-induced DNA fragmentation, whereas pretreatment of PMNL with B287 restored DNA degradation in the presence of BCF from 60190 strain (Fig. 3). 

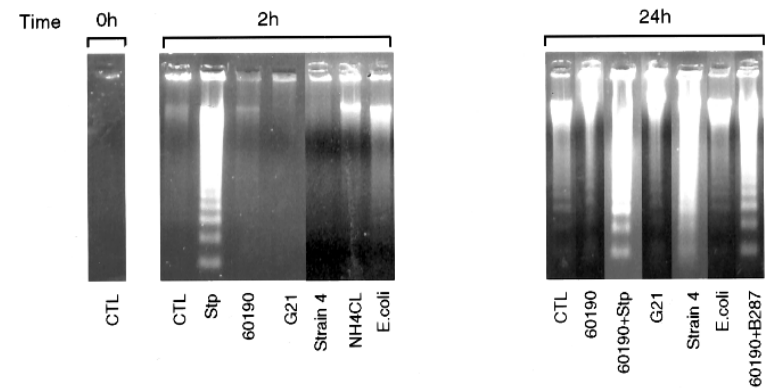

Figure 3.

DNA laddering analysis. DNA obtained, after 2 hours or 24 hours of culture, from control (CTL) PMNL and from treated PMNL, with either BCF from 60190, G21 and Strain 4 strains of $H$. pylori, lipopolysaccharide (LPS) from E. coli 055: $\mathrm{B} 5, \mathrm{NH}_{4} \mathrm{Cl}$, staurosporine (Stp), or BCF from 60190 pretreated with B287, were separated on a $2 \%$ agarose gel containing ethidium bromide. The results are representative of three separate experiments using PMNL isolated from three different donors.

\section{Procaspases 3 and 8 Activation in PMNL after 2- or 24-Hour Incubation with BCF from H. pylori Strains}

We followed the activation of both caspases 3 and 8 by the cleavage of their respective zymogens of 32 and $52 \mathrm{kDa}$. As shown in Figure 4, staurosporine clearly induced the disappearance of procaspases 3 and 8 , which reflects the activation of these two cysteine proteinase. BCF from various $H$. pylori strains clearly inhibited caspase 3 and caspase 8 activation at 2 hours and 24 hours. B287 significantly counteracted the effect of BCF from $60190 \mathrm{H}$. pylori strain at both 2 and 24 hours. As already reported for the TUNEL assay, BCF from the $60190 \mathrm{H}$. pylori strain failed to inhibit staurosporine-mediated activation of caspase 3 and caspase 8 (Fig. 4).

\section{Measurement of Caspase Activity in PMNL Incubated with BCF from $\mathrm{H}$. pylori}

We next analyzed caspase activity in culture PMNL by using Ac-DEVD-pNA as substrate. Caspase activity was virtually undetectable in freshly isolated PMNL (Control 1), but was induced after 24 hours of culture (Control 2) (Fig. 5). Caspase activity in PMNL incubated 24 hours with BCF from 60190, 60190:v1, 60190:C-, 60190:M22, G21, and strain 4 H. pylori strains was strongly decreased compared with control PMNL cultured for 24 hours ( $1.5 \pm 0.5$ vs $1.2 \pm 0.3$ vs

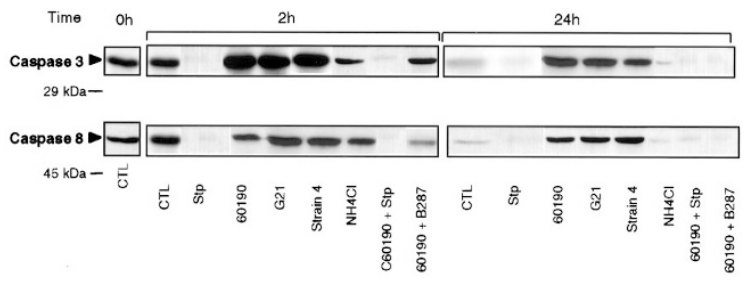

Figure 4.

Procaspase 3 and 8 activation in PMNL. After either 2 hours or 24 hours incubation with BCF from different $H$. pylori strains (60190, G21, strain 4), caspases 3 and 8 were strongly expressed in PMNL. Stp, staurosporine. The results are representative of three separate experiments using PMNL isolated from three different donors.
$1.4 \pm 0.3$ vs $1.1 \pm 0.4$ vs $1.4 \pm 0.2$ vs $1.25 \pm 0.5$ vs $3.6 \pm 0.3 \mathrm{~mm} / \mathrm{min} \cdot \mathrm{mg}$, for 60190 vs 60190:v1 vs 60190:C - vs 60190:M22 vs G21 vs strain 4 vs control, respectively, at 24 hours) (Fig. 5). Caspase activity in PMNL treated with $\mathrm{NH}_{4} \mathrm{Cl}(3 \mathrm{~mm})$ and in PMNL incubated with BCF from $60190 \mathrm{H}$. pylori treated with B287 was similar to control cells at 24 hours in culture ( $3.8 \pm 0.4$ vs $4 \pm 0.3$ versus $3.6 \pm 0.3 \mathrm{~mm} / \mathrm{min} \cdot \mathrm{mg}$, for $\mathrm{NH}_{4} \mathrm{Cl}$-treated PMNL vs $60190 \mathrm{BCF}$ treated with B287 vs control, respectively, at 24 hours). Similar results were obtained in PMNL incubated with BCF from 60190:v1 or 60190:C - or 60190:M22 H. pylori-treated with B287 (data not shown).

\section{BCF from H. pylori Induced P42/44 ${ }^{M A P k}$ Activation in PMNL}

As shown in Figure $6 \mathrm{~A}, \mathrm{P} 42 / 44^{\mathrm{MAPk}}$ was rapidly induced in PMNL-treated with BCF. The effects of BCF from $60190 \mathrm{H}$. pylori strain was observed as soon as 2 minutes, was maximal at 5 minutes, and then rapidly decreased (Fig. 6A). The kinetics of BCF-mediated activation of $\mathrm{P} 42 / 44^{\mathrm{MAPk}}$ was indistinguishable from that of $\mathrm{fMLP}$, which served as a positive control, although the extent of $\mathrm{P} 42 / 44^{\mathrm{MAPk}}$ phosphorylation was lower in BCF-treated cells than in fMLP-treated cells. No activation was noted in control PMNL. All BCF from $H$. pylori used in this study showed similar activation of $\mathrm{P} 42 / 44^{\mathrm{MAPk}}$ at 5 minutes, whereas this

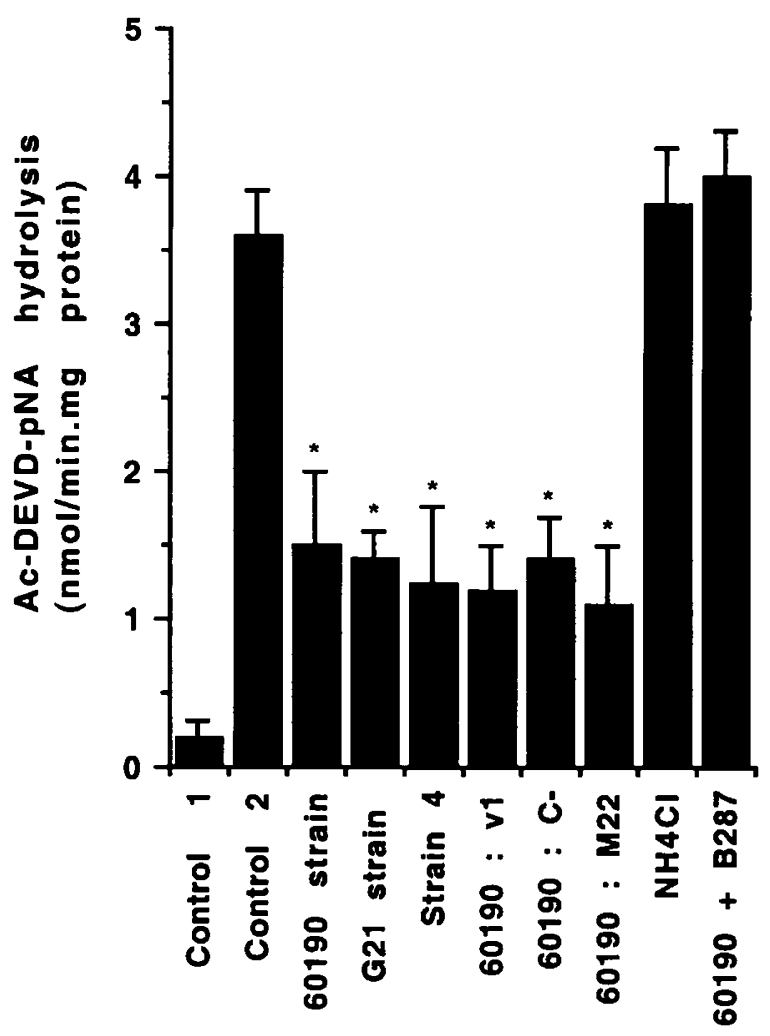

Figure 5.

Caspase 3 activity in PMNL measured with a continuous colorimetric assay. Control 1: caspase activity in PMNL at 0 hours in culture medium; Control 2 . caspase activity in PMNL at 24 hours in culture medium. The results are the means of three independent experiments $\left({ }^{*} p<0.01\right)$. 
activation was strongly decreased by using BCF from 60190 treated with $\mathrm{B} 287$ or by using culture medium containing $3 \mathrm{mM} \mathrm{NH}_{4} \mathrm{Cl}$ (Fig. 6A). PD98059 significantly attenuated BCF delay of PMNL apoptosis, because apoptosis was induced similarly by PD98059 treatment in PMNL incubated with BCF from 60190 strain and in control PMNL (Fig. 6B) $(92 \% \pm 5 \%$ vs $89 \% \pm 8 \%$ for 60190 strain and control cells, respectively).

\section{Discussion}

The low biologic activity of $H$. pylori LPS has been extensively documented (Birkholz et al, 1993; Moran, 1995; Muotiala et al, 1992; Nielsen et al, 1994). In particular, $H$. pylori LPS induces a significantly lower oxidative metabolism, enzyme, and cytokine release than other known bacterial LPS (Birkholz et al, 1993; Nielsen et al, 1994). Previous studies have shown that there is a structure-function relationship of LPS and that lipid $A$ is the biologically active part of the LPS molecule (Kanegasaki et al, 1986; Loppnow et al, 1989). The low potency of LPS from $H$. pylori is therefore probably due to the unusual acylation and phosphorylation pattern of its lipid A (Muotiala et al, 1992). In the present study, we provide for the first time evidence that, despite this low biologic potency, $H$. pylori LPS can dramatically hinder spontaneous PMNL apoptosis. This effect was similar to that obtained with LPS from $E$. coli.

Several $H$. pylori products can enter the extracellular space and interact with PMNL via several different

A
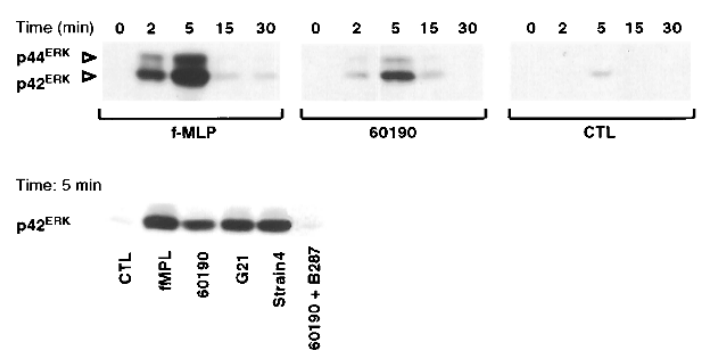

B

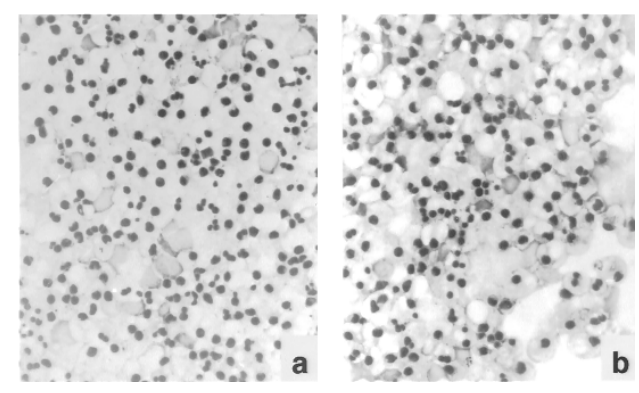

Figure 6.

A, P42/44 MAPkinase activity in PMNL at 5 minutes after incubation with BCF from different strains of $H$. pylori $\left(60190, \mathrm{G} 21\right.$, strain 4), with $\mathrm{NH}_{4} \mathrm{Cl}(3 \mathrm{~mm})$, with staurosporine $(1 \mu \mathrm{M})$. These P42/44 ${ }^{\mathrm{MAPk}}$ activations were compared with those obtained at 5 minutes for control (CTL) PMNL and for PMNL treated with formyl-Met-Leu-Phe $(f M L P)\left(10^{-7} \mathrm{M}\right)$ or with BCF from $60190 \mathrm{H}$. pylori strain. $B$, Effect of PD98059 treatment in PMNL incubated with BCF from 60190 strain of $H$. pylori: a, control cells at 24 hours, b, PMNL incubated with BCF from 60190 strain at 24 hours. mechanisms: (a) some proteins, like VacA, are specifically secreted (Schraw et al, 1999); (b) bacterial autolysis can release proteins (Phadnis et al, 1996); and (c) $H$. pylori releases membrane vesicles or blebs (Fiocca et al, 1999). Moreover, it has been demonstrated that LPS from several bacterial species can enter in the subepithelial space by epithelia transcytosis and have the capacity to stimulate basolaterally positioned PMNL to migrate into the paracellular space (Beatty and Sansonetti, 1997). VacA toxin is one of the major virulence factors produced by $H$. pylori (Cover, 1996), but its effect on PMNL behavior has not been well investigated. Urease on the $H$. pylori surface is a potent chemotactic factor for human leukocytes; it causes recruitment and activation of phagocytes, leading to gastric mucosal injury (Harris et al, 1996). Moreover, it has been reported that ammonia generated by $H$. pylori can reduce the production of reactive oxygen intermediates of PMNL (Mayo et al, 1997). Previous studies have demonstrated that ammonia evokes the depolymerization of PMNL actin cytoskeleton, decreases granule release induced by formylpeptides (Brunkhorst and Niederman, 1991), diminishes PMNL chemotaxis (Samanta et al, 1990), and inhibits fusion between phagosomes and lysosomes (Gordon et al, 1980). Finally, alkalinization of the environment due to release of ammonia may accelerate PMNL apoptosis (Leblebicioglu and Walters, 1999). The cag region of the $H$. pylori chromosome contains the gene encoding the cytotoxinassociated antigen (CagA) and may contain two adjacent genes, picA and picB (Blaser, 1997; Censini et al, 1996; Covacci et al, 1999). Gene products from cagA and picB may be present in the extracellular spaces and are implicated in the production, secretion, or anchorage of a protein involved in transducing the IL-8 inducing signal to epithelial cells (Cao et al, 1998; Crabtree et al, 1995). The effect of these products on PMNL behavior is still largely unknown. However, recent studies have shown that in PMNL, upregulation of $C D 11 \mathrm{~b}$, oxidative burst, and chemotaxis are not associated with the presence of $\operatorname{cag} \mathrm{A}$ or pic $\mathrm{B}$ pattern (Akyon and Hascelik, 1999; Hansen et al, 1999a, 1999b). In our study, no relationship was found between hindered programmed cell death of PMNL in relation to genotypes for cag $\mathrm{PAI}, \mathrm{VacA}$, and urease: protection against apoptosis was not observed using BCF from the different strains tested, after removal of LPS with the antagonist B287. Finally our data highlight that LPS was the only component present in BCF obtained from different strains of $H$. pylori able to hinder PMNL apoptosis.

The hallmark of PMNL biology is their high capacity for spontaneous apoptosis. Rapid induction of apoptosis in PMNL, and the subsequent engulfment of the apoptotic cells by phagocytes are important in the rapid resolution of inflammation (Haslett, 1992; Savill et al, 1989). This is necessary to avoid unwanted tissue damage caused by the rapid release of the cellular contents of apoptotic PMNL (Haslett, 1992; Savill et al, 1989). It has been recently shown that caspases 3 and 8 are expressed in PMNL and that 
TNF $\alpha$-induced PMNL apoptosis involves these caspases (Yamashita et al, 1999). In our study we showed that $H$. pylori LPS strongly inhibit procaspase 3 and 8 activation in PMNL at 24 hours. We next analyzed the involvement of $\mathrm{p} 42 / 44^{\mathrm{MAPk}}$ in the protective effect of $H$. pylori LPS from BCF on PMNL apoptosis. Three distinct classes within the mitogenactivated protein (MAP) kinase family have been described, including p42/44 ${ }^{\mathrm{MAPk}}$, JNK kinase, and p38, each having different physiologic roles (Paul et al, 1997). A specific function for MAP kinases has been proposed to play an important role in the respiratory burst, IL-8 production, and apoptosis of PMNL (Aoshiba et al, 1999; Frasch et al, 1998). Indeed, p42/ $44^{\mathrm{MAPk}}$ are involved in the protection of PMNL against apoptosis (Downey et al, 1998). In our study we demonstrated that LPS from $H$. pylori activates the $\mathrm{p} 42 / 44^{\mathrm{MAPk}}$. This effect of $H$. pylori LPS on $\mathrm{p} 42 /$ $44^{\mathrm{MAPk}}$ may account for the inhibitory effect of BCF from $H$. pylori on PMNL apoptosis. Moreover, PMNL undergo marked phenotypic changes during the process of spontaneous apoptosis, such as reduced expression of CD62L, CD15, CD16, and CD43 and increased expression of CD11b/CD18 and CD11c/ CD18 (Dransfield et al, 1995; Homburg et al, 1995). Finally, in addition to LPS, it has been shown that PMNL apoptosis is delayed by several cytokines, such as granulocyte colony stimulating factor, granulocytemacrophage colony stimulating factor, IL-8, and IFN $\gamma$ (Colotta et al, 1992; Klein et al, 2000; Lee et al, 1993, Leuenroth et al, 1998; Yamamoto et al, 1993).

The exact mechanisms involved in the protective effect of LPS on programmed cell death in human PMNL are presently not well understood. However inhibition of PMNL apoptosis by LPS greatly prolonged their functional longevity as assessed by a number of parameters, including chemotaxis, phagocytosis, and stimulated secretion (Lee et al, 1993). In vivo, $H$. pylori LPS is probably not the only mechanism that can prevent or hinder the apoptosis of PMNL. Proinflammatory cytokines, such as IL-8 or GM-CSF, can be released by epithelial cells after bacterial infection, and these cytokines can prevent PMNL apoptosis (Hofman et al, 2000; Klein et al, 2000; Leuenroth et al, 1998; Yamamoto et al, 1993). However, considering that only some virulent strains of $H$. pylori are able to induce IL-8 secretion by epithelial cells (Hofman et al, 2000), our results show that $H$. pylori strains can hinder PMNL apoptosis independently of the cag status. Although $H$. pylori LPS has not yet been demonstrated in the lamina propria, bacterial LPS may be in contact with PMNL after epithelium destruction or tight junction opening, or after transepithelial migration. Finally, as shown for Shigella LPS, $H$. pylori LPS may be released in the subepithelial space and may be in contact with PMNL (Beatty et al, 1999).

The consequences of the increased survival of PMNL in the gastric mucosa induced by $H$. pylori LPS may be to induce gastric epithelium injury by excessive release of proteinases and radical oxygen intermediates. Thus, inhibition of apoptosis during infec- tion may contribute greatly to the severity of epithelium injury.

In conclusion, although the immunogenicity and biologic activity of the $H$. pylori LPS on PMNL is low, it nevertheless appears to dramatically contribute to pathogenicity by modulating PMNL programmed cell death. This delay in PMNL apoptosis may enhance inflammation and result in aggravation of PMNLmediated tissue damage in $H$. pylori-associated diseases. Elucidation of the precise roles in vivo of this delay may provide therapeutic advantages against $H$. pylori infection.

\section{Materials and Methods}

\section{Bacterial Strains and Preparation of BCF}

We used the urease ${ }^{+} \mathrm{NacA}^{+} / \mathrm{cag}^{+}$wild-type $\mathrm{H}$. pylori 60190 strain (American Type Culture Collection 49503; Rockville, Maryland), its urease-negative spontaneous mutant (strain 4) (Perez-Perez et al, 1992), and its isogenic mutants in which vac $A$ (60190:v1) or cagA (60190:M22) or picB/cagE (60190:C-) genes were disrupted by insertional mutagenesis (Cover et al, 1994; Ghiara et al, 1995; Tummuru et al, 1994, 1995) (these strains have been kindly given by T. L. Cover and M. J. Blaser, Nashville, Tennessee). In addition, we used the wild-type G21 (urease ${ }^{+} \mathrm{NacA}^{-}$/ $\left.\mathrm{cag}^{-}\right) \mathrm{H}$. pylori strain (kindly given by N. Figura, Sienna, Italy) (Ghiara et al, 1995). BCF were prepared as previously described (Ricci et al, 1997). Briefly, bacteria were grown in Brucella broth (Difco, Detroit, Michigan) supplemented with $1 \%$ Vitox (Oxoid, Basingstoke, United Kingdom) and 5\% FCS (GIBCO BRL, Paisley, Scotland) for 24 to 36 hours at $37^{\circ} \mathrm{C}$ in a thermostatic shaker under microaerophilic conditions. When the bacterial suspensions reached 1.2 units of optical density at $450 \mathrm{~nm}$ (corresponding to a bacterial concentration of $5 \times 10^{8} \mathrm{CFU} / \mathrm{ml}$ ), bacteria were removed by centrifugation, and the supernatants were sterilized by passage through a $0.22-\mu \mathrm{m}$ pore-size cellulose acetate filter to obtain BCF. BCF were diluted 1:3. The vacuolating power of $\mathrm{VacA}^{+} \mathrm{BCF}$ prepared and used as described is equivalent to that exhibited by a final concentration of $0.4 \mu \mathrm{g} / \mathrm{ml}$ purified VacA (VR, personal observation). For some experiments we also used BCF from $E$. coli 055:B5 strain. The concentrations of LPS in BCF used in this study were evaluated with a limulus test (BioWhittaker, Walkersville, Maryland).

\section{PMNL Preparation and Incubation}

Human PMNL were isolated from whole blood using a gelatin-sedimentation technique (Hofman et al, 1996). Briefly, whole blood anticoagulated with citrate/dextrose was centrifuged at $300 \times g$ for 20 minutes $\left(20^{\circ} \mathrm{C}\right)$. The plasma and buffy coat were removed and the gelatin/cell mixture was incubated at $37^{\circ} \mathrm{C}$ for 30 minutes to remove contaminating red blood cells. Residual red blood cells were then lysed with isotonic ammonium chordee. After washing in HBSS without $\mathrm{Ca}^{2+}$ or $\mathrm{Mg}^{2+}$, the cells were counted and resus- 
pended at $5 \times 10^{7} \mathrm{PMNL} / \mathrm{ml}$. PMNL (95\% pure) with $98 \%$ viability by trypan blue exclusion were used within 1 hour after isolation.

PMNL were incubated with $H$. pylori BCF containing $400 \mathrm{ng} / \mathrm{ml}$ LPS. In some experiments $E$. coli LPS ( $E$. coli 055:B5 LPS; Sigma, Paris, France) (400 ng/ml) was used as a control. In other experiments the LPS antagonist B287 (Eisai Institute, Andover, Massachusetts) was added to the different BCF before incubation with PMNL (Golenbock et al, 1991). B287 is a synthetic compound whose structure is identical to the proposed structure of $R$. sphaeroides lipid A (Golenbock et al, 1991).

\section{Morphologic Analysis}

Morphologic changes of apoptosis were demonstrated by light microscopic examination of WrightGiemsa-stained cytospins. Briefly, control PMNL and treated PMNL were fixed with methanol, stained, and the slides were examined by oil-immersion light microscopy (original magnification, $\times 1,000$ ). At least 400 cells of each preparation in different fields of view were counted. Apoptotic cells were easily distinguishable by their reduced volume, chromatin condensation, and nuclear fragmentation.

Detection of apoptotic PMNL was performed by using TUNEL staining. TUNEL staining of the apoptotic cells was performed as described previously (Karahashi and Amano, 1998). In brief, PMNL were seeded at $4 \times 10^{4}$ cells $/ 100 \mu$ l of the medium into the wells in a slide glass, and preincubated. The cells were fixed directly with $3 \%$ formaldehyde in the culture medium, $\mathrm{pH} 7.0$, extensively washed with PBS, and stained with an Apotosis in Situ Detection Kit (Roche, Paris, France) according to the manufacturer's protocol. Stained cells were observed using a laser scanning fluorescence microscope (Leica, Lyon, France) equipped for epifluorescence, and photographs were taken in random fields. To better quantify the apoptotic cells, $1 \times 10^{6} \mathrm{PMNL}$ per condition were fixed in paraformaldehyde $3.7 \%$ and stained using the TUNEL assay as described above, and were analyzed by flow cytometry using a FACS Becton Dickinson (Paris, France).

\section{DNA Fragmentation Assay}

DNA was isolated from $1 \times 10^{7}$ control and treated PMNL. PMNL DNA fragmentation was conducted according to the procedure for assaying DNA fragmentation in total genomic DNA. In brief, the cells were lysed with TES buffer $(20 \mathrm{~mm}$ Tris HCL, $200 \mathrm{~mm}$ EDTA, and $1 \%$ SDS) with RNAse $(20 \mu \mathrm{g} / \mathrm{ml}$; Boehringer Mannheim, Indianapolis, Indiana) at $37^{\circ} \mathrm{C}$ for 1 hour. Proteins were denatured by incubation with proteinase $\mathrm{K}(1 \mathrm{mg} / \mathrm{ml}$; Boehringer Mannheim) at $55^{\circ} \mathrm{C}$ for 3 hours. The denatured protein was removed by phenol extraction. The DNA was then precipitated with alcohol overnight at $-20^{\circ} \mathrm{C}$. DNA was rinsed with alcohol, mixed with loading buffer, and then electrophoresed in a $2 \%$ agarose gel containing $10 \mu \mathrm{g} / \mathrm{ml}$ ethidium bromide. The gel was examined and photographed under ultraviolet light to detect a regular DNA fragmentation pattern (laddering) characteristic of apoptosis.

\section{Western Blotting for Caspases 3 and 8 and p42/44}

Control and treated PMNL were washed in Hanks' balanced salt solution (Sigma), then in lysis buffer at $4^{\circ} \mathrm{C}(50 \mathrm{~mm}$ Tris- $\mathrm{HCl}$ [pH 7.4], $150 \mathrm{~mm} \mathrm{NaCl}, 2 \mathrm{~mm}$ EDTA, $1 \%$ NP40, 1 mM Na $\mathrm{VO}_{4}, 1 \mathrm{~mm}$ phenylmethylsulfonyl fluoride, $25 \mu \mathrm{m}$ leupeptin, $5 \mathrm{~mm}$ benzamidin, 1 $\mu \mathrm{M}$ pepstatin, $25 \mu \mathrm{M}$ aprotinin, $50 \mathrm{~mm}$ sodium $\beta$-glycerophosphate, $20 \mathrm{~mm}$ sodium pyrophosphate, $0.5 \mathrm{~mm}$ dithiothreitol) at a density of $5 \times 10^{7} \mathrm{cell} / \mathrm{ml}$. After sonication (2 pulses of 8 seconds each), lysates were centrifuged at $15,000 \times g$ for 15 minutes at $4^{\circ} \mathrm{C}$ and denatured by boiling in reducing SDS sample buffer. Protein lysates (50 $\mu \mathrm{g}$ per sample) were analyzed by migration in SDS-PAGE and subsequently were electrophoretically transferred to nitrocellulose membrane. Nitrocellulose membrane was incubated in saturation buffer then probed with anti-phosphop42/44 ${ }^{\mathrm{MAPk}}$ (diluted 1:2,000) (New England BioLabs, Boston, Massachusetts) antibody incubated overnight at $4^{\circ} \mathrm{C}$. This labeling was visualized by peroxidaseconjugated secondary antibodies (antirabbit lgG) $(1: 3,000)$ (Dakopatts, Copenhagen, Denmark) and by enhanced chemiluminescence (ECL kit; Amersham International, Buckinghamshire, United Kingdom). As positive control for $\mathrm{p} 42 / 44^{\mathrm{MAPk}}$ activation, we used the chemoattractant formyl-Met-Leu-Phe (fMLP) $\left(10^{-7}\right.$ $\mathrm{M})$, because it was previously demonstrated that $\mathrm{fMLP}$ both activated p42/44 ${ }^{\mathrm{MAPk}}$ and delayed PMNL apoptosis (Avdi et al, 1996; Murray et al, 1997). To determine if $H$. pylori-LPS delays PMNL apoptosis by activation of $\mathrm{p} 42 / 44^{\mathrm{MAPk}}$, we used the ERK pathway inhibitor PD98059 (Biomol Research Laboratories, Plymouth, Pennsylvania), 1 hour at $10 \mu \mathrm{M}$, before PMNL incubation with the different BCF from $\mathrm{H}$. pylori as described above. PMNL apoptosis was evaluated by light microscopy as previously described in this study.

\section{Ac-DEVD-pNA Cleavage Assay}

Caspase activity was measured using kinetic colorimetric assay. Briefly, control or treated PMNL were sonicated (2 pulses of 8 seconds each), and then the lysates were centrifuged at $15,000 \times g$. Cell extracts (50 $\mu \mathrm{g}$ per sample) were incubated with $200 \mu \mathrm{M}$ of Ac-Asp-Glu-Val-Asp-pNA (Ac-DEVD-pNA; Alexis Corporation, Paris, France) preferentially cleaved by members of the caspase 3 family of cysteine protease. Liberation of pNA was monitored continuously at $37^{\circ} \mathrm{C}$ by using an excitation wavelength of $410 \mathrm{~nm}$. Measurements were recorded over the linear range of the assay, and caspase activity was controlled by adding to the cell extract an apopain/CPP-32 inhibitor (Ac-DEVD-CHO; Alexis Corporation). Substrates without lysates served as negative controls. 


\section{Acknowledgements}

The authors thank Mireille Mari and Dominique Sadoulet for their technical assistance. Vittorio Ricci was a visiting scientist (Poste Vert INSERM) from the University of Pavia Medical School (Pavia, Italy).

\section{References}

Akyon Y and Hascelik G (1999). The effect of Helicobacter pylori on neutrophil chemotaxis is independent of cagA. FEMS Immunol Med Microbiol 24:209-213.

Aoshiba K, Yasui S, Hayashi M, Tamaoki J, and Nagai A (1999). Role of p38-mitogen-activated protein kinase in spontaneous apoptosis of human neutrophils. J Immunol 162:1692-1700.

Avdi N J, Winston B W, Russel M, Young S K, Johnson G L, and Worthen G S (1996). Activation of MEKK by formylmethionyl-leucyl-phenylalanine in human neutrophils. Mapping pathways for mitogen-activated protein kinase activation. J Biol Chem 271:33598-33606.

Beatty WL, Méresse S, Gounon P, Davoust J, Mounier J, Sansonetti PJ, and Gorvel JP (1999). Trafficking of Shigella lipopolysaccharide in polarized intestinal epithelial cells. J Cell Biol 145:689-698.

Beatty WL and Sansonetti P J (1997). Role of lipopolysaccharide in signaling to subepithelial polymorphonuclear leukocytes. Infect Immun 65:4395-4404.

Birkholz S, Knipp U, Nietzki C, Adamek R J, and Opferkuch W (1993). Immunological activity of lipopolysaccharide of Helicobacter pylori on human peripheral mononuclear blood cells in comparison to lipopolysaccharides of other intestinal bacteria. FEMS Immunol Med Microbiol 6:317-324.

Blaser MJ (1997). Ecology of Helicobacter pylori in the human stomach. J Clin Invest 100:759-762.

Brunkhorst B and Niederman R (1991). Ammonium decreases human polymorphonuclear leukocyte cytoskeletal actin. Infect Immun 59:1378-1386.

Cao P, McClain MS, Forsyth MH, and Cover TL (1998). Extracellular release of antigenic proteins by Helicobacter pylori. Infect Immun 66:2984-2986.

Censini S, Lange C, Xiang Z, Crabtree JE, Ghiara P, Borodovsky M, Rappuoli R, and Covacci A (1996). Cag, a pathogenicity island of Helicobacter pylori, encodes type I-specific and disease-associated virulence factors. Proc Natl Acad Sci USA 93:14648-14653.

Colotta F, Re F, Polentarutti N, Sozzani S, and Mantovani A (1992). Modulation of granulocyte survival and programmed cell death by cytokines and bacterial products. Blood 80 : 2012-2020.

Covacci A, Telford JL, del Giudice G, Parsonnet J, and Rappuoli R (1999). Helicobacter pylori virulence and genetic geography. Science 284:1328-1333.

Cover TL (1996). The vacuolating cytotoxin of Helicobacter pylori. Mol Microbiol 20:241-246.

Cover TL, Tummuru MKR, Cao P, Thompson SA, and Blaser MJ (1994). Divergence of genetic sequences for the vacuolating cytotoxin among Helicobacter pylori strains. J Biol Chem 269:10566-10573.
Crabtree JE, Covacci A, Farmery SM, Xiang Z, Tompkins DS, Perry S, Lindleey IJD, and Rappuoli R (1995). Helicobacter pylori induced interleukin-8 expression in gastric epithelial cells is associated with cagA positive phenotype. J Clin Pathol 48:41-45.

Davies GR, Simmonds NJ, Stevens TRJ, Sheaff MT, Babatvala N, Laurenson IF, Blake DR, and Rampton DS (1994). Helicobacter pylori stimulates antral mucosal reactive oxygen metabolite production in vivo. Gut 35:179-185.

Downey GP, Butler JR, Tapper H, Fialkow L, Saltiel AR, Rubin $B B$, and Grinstein S (1998). Importance of MEK in neutrophil microbiocidal responsiveness. J Immunol 160:434-443.

Dransfield I, Stocks SC, and Haslett C (1995). Regulation of cell adhesion molecule expression and function associated with neutrophil apoptosis. Blood 85:3264-3273.

Evans DJ, Evans DG, Takemur T, Nakano H, Lambert HC, Graham DY, Granger DN, and Kvietys PR (1995). Characterization of a Helicobacter pylori neutrophil-activating protein. Infect Immun 63:2213-2220.

Fiocca R, Necchi V, Sommi P, Ricci V, Telford J, Cover TL, and Solcia E (1999). Release of Helicobacter pylori vacuolating cytotoxin by both a specific secretion pathway and budding of outer membrane vesicle: Uptake of released toxin and vesicles by gastric epithelium. J Pathol 188:220-226.

Frasch SC, Nick JA, Fadok VA, Bratton DL, Worthen GS, and Henson PM (1998). P38 Mitogen-activated protein kinasedependent and-independent intracellular signal transduction pathways leading to apoptosis in human PMNL. J Biol Chem 273:8389-8397.

Geis, G, Leying H, Suerbaum S, and Opferkuch W (1990). Unusual fatty acid substitution in lipids and lipopolysaccharides of Helicobacter pylori. J Clin Microbiol 28:930-932.

Ghiara P, Marcheti M, Blaser MJ, Tummuru MKR, Cover T L, Segal E D, Tomkins L S, and Rappuoli R (1995). Role of the Helicobacter pylori virulence factors vacuolating cytotoxin, CagA, and urease in a mouse model of disease. Infect Immun 63:4154-4160.

Golenbock DT, Hampton R Y, Qureshi N, Takayama K, and Raetz C R (1991). Lipid A-like molecules that antagonize the effects of endotoxins on human monocytes. J Biol Chem 266:19490-19498.

Gordon A H, D'Arcy Hart P, and Young MR (1980). Ammonia inhibits phagosome-lysosome fusion in macrophages. $\mathrm{Na}$ ture 286:79-80.

Hansen PS, Go MF, Varming K, Andersen LP, Genta RM, Graham DY, and Nielsen H (1999a) Proinflammatory activation of PMNL and monocytes by Helicobacter pylori in patients with different clinical presentation. Infect Immun 67:3171-3174.

Hansen PS, Go MF, Varming K, Andersen LP, Graham DY, and Nielsen H (1999b) Proinflammatory activation of neutrophils and monocytes by Helicobacter pylori is not associated with cagA, vacA or picB genotypes. APMIS 107:1117-1123.

Harris PR, Mobley HLT, Perez-Perez GI, Blaser MJ, and Smith PD (1996). Helicobacter pylori urease is a potent stimulus of mononuclear phagocyte activation and inflammatory cytokine production. Gastroenterology 111:419-425.

Haslett C (1992). Resolution of acute inflammation and the role of apoptosis in the tissue fate of granulocytes. Clin Sci (Colch) 83:639-648. 
Hofman P, D'Andrea L, Carnes D, Colgan SP, and Madara JL (1996). The actin cytoskeleton of intestinal epithelial cells selectively constrains lumen to tissue directed migration of PMNL. Am J Physiol 271:312-320.

Hofman V, Ricci V, Galmiche A, Brest P, Auberger P, Rossi B, and Hofman P (2000). Effect of Helicobacter pylori on polymorphonuclear leukocyte migration across polarized T84 epithelial cell monolayers: Role of the vacuolating toxin VacA and the cag pathogenicity island. Infect Immun 68:52255233.

Homburg CHE, de Haas M, von dem Borne AEGK, Verhoeven AJ, Reutelingsperger CPM, and Roos D (1995). Human neutrophils loose their surface Fc $\gamma$ RIII and acquire Annexin V binding sites during apoptosis in vitro. Blood 85:532-540.

Kanegasaki S, Tanamoto K, Yasuda T, Homma JY, Matsura M, Nakatsuka $M$, Kumazawa $Y$, Yamamoto $A$, Shiba $T$, Kusumoto $\mathrm{S}$, Imoto $\mathrm{M}$, Yoshimura $\mathrm{H}$, and Shimamoto $\mathrm{T}$ (1986). Structure-activity relationship of lipid A: Comparison of biological activities of natural and synthetic lipid A's with different fatty acid compositions. J Biochem (Tokyo) 99: 1203-1210.

Karahashi H and Amano F (1998). Apoptotic changes preceding necrosis in lipopolysaccharide-treated macrophages in the presence of cycloheximide. Exp Cell Res 241:373-383.

Keenan J, Day T, Neal S, Cook B, Perez-Perez G, Allardyce $R$, and Baggshaw P (1999). A role for the bacterial outer membrane in the pathogenesis of Helicobacter pylori infection. FEMS Microbiol Lett 182:259-264.

Klein JB, Rane MJ, Scherzer JA, Coxon PY, Kettriz R, Mathiesen JM, Buridi A, and McLeish KR (2000). Granulocyte-macrophage colony-stimulating factor delays neutrophil constitutive apoptosis through phosphoinositide 3-kinase and extracellular signal-regulated kinase pathways. J Immunol 164:4286-4291.

Labigne A and de Reuse H (1996). Determinants of Helicobacter pylori pathogenicity. Infect Agents Dis 5:191-202.

Leblebicioglu B and Walters J (1999). Alkaline conditions accelerate polymorphonuclear leukocyte apoptosis in vitro. Infect Immun 67:2019-2021.

Lee A, Whyte MKB, and Haslett C (1993). Inhibition of apoptosis and prolongation of neutrophil functional longevity by inflammatory mediators. J Leukoc Biol 54:283-288.

Leuenroth S, Lee C, Grutkoski P, Keeping H, and Simms H (1998). Interleukin-8-induced suppression of polymorphonuclear leukocyte apoptosis is mediated by suppressing CD95 (Fas/Apo-1) Fas-1 interactions. Surgery 124:409-417.

Loppnow H, Brade H, DÅrrbaum I, Dinarello CA, Kusumoto S, Riestschel ET, and Flad HD (1989). IL1 induction capacity of defined lipopolysaccharide partial structures. J Immunol 142:3229-3238.

Mai UEH, Perez-Perez GI, Allen JB, Wahl SM, Blaser MJ, and Smith PD (1992). Surface proteins from Helicobacter pylori exhibit chemotactic activity for human leukocytes and are present in gastric mucosa. J Exp Med 175:517-525.

Mai UEH, Perez-Perez GI, Wahl LM, Wahl SM, Blaser MJ, and Smith PD (1991). Soluble surface proteins from Helicobacter pylori activate monocytes/macrophages by lipopolysaccharide-independent mechanism. J Clin Invest 87:894-900.

Mayo K, Held M, Wadström T, and Megraud F (1997). Helicobacter pylori-human polymorphonuclear leukocyte in- teraction in the presence of ammonia. Eur $\mathrm{J}$ Gastroenterol Hepatol 9:457-461.

Mizuki T, Shimoyama T, Fukuda S, Liu Q, Nakaji S, and Munakata A (2000). Association of gastric epithelial apoptosis with the ability of Helicobacter pylori to induce a neutrophil oxidative burst. J Med Microbiol 49:521-524.

Moran AP (1995). Cell surface characteristics of Helicobacter pylori. FEMS Immunol Med Microbiol 10:271-280.

Muotiala A, Helander IM, Pyahala L, Kosunen TU, and Moran AP (1992). Low biological activity of Helicobacter pylori lipopolysaccharide. Infect Immun 60:1714-1716.

Murray J, Barbara JA, Dunkley SA, Lopez AF, Van Ostade X, Condliffe AM, Dransfield I, Haslett C, and Chilvers ER (1997). Regulation of neutrophil apoptosis by tumor necrosis factor- $\alpha$ : Requirement for TNFR55 and TNFR75 for induction of apoptosis in vitro. Blood 90:2772-2783.

Nielsen H, Birkholz S, Andersen LP, and Moran AP (1994). Neutrophil activation by Helicobacter pylori lipopolysaccharides. J Infect Dis 170:135-139.

Paul A, Wilson S, Belham CM, Robinson CJ, Scott PH, Gould GW, and Plevin R (1997). Stress-activated protein kinases: Activation, regulation and function. Cell Signal 9:403-410.

Perez-Perez GI, Olivares AS., Cover TL, and Blaser MJ (1992). Characteristics of Helicobacter pylori variants selected for urease deficiency. Infect Immun 60:3658-3663.

Phadnis SH., Parlow MH, Levy M, Ilver C, Caulkins CM, Connors JB, and Dunn BE (1996). Surface localization of Helicobacter pylori urease and a heat shock protein homolog requires bacterial autolysis. Infect Immun 64:905-912.

Ricci V, Sommi R, Fiocca M, Romano M, Solcia E, and Ventura U (1997). Helicobacter pylori vacuolating toxin accumulates within the endosomal-vacuolar compartment of cultured gastric cells and potentiates the vacuolating activity of ammonia. J Pathol 183:453-459.

Samanta AK, Oppenheim JJ, and Matsushima K (1990). Interleukin-8 (monocyte-derived neutrophil chemotactic factor) dynamically regulates its own receptor expression on human neutrophils. J Biol Chem 265:183-189.

Savill JS, Wyllie AH, Henson JE, Walport MJ, Henson PM, and Haslett C (1989). Macrophage phagocytosis of aging neutrophils in inflammation: Programmed cell death in the neutrophil leads to its recognition by macrophages. $\mathrm{J}$ Clin Invest 83:865-875.

Schraw W, McClain MS, and Cover TL (1999). Kinetics and mechanisms of extracellular protein release by Helicobacter pylori. Infect Immun 67:5247-5252.

Suzuki, M, Miura S, Suematsu M, Fukumura D, Kurose I, Suzuki H, Kai A, Kudoh Y, Ohashi M, and Tsuchiya M (1992). Helicobacter pylori-associated ammonia production enhance neutrophil-dependent gastric mucosal cell injury. Am J Physiol 263:719-725.

Tummuru MKR, Cover TL, and Blaser MJ (1994). Mutation of the cytotoxin-associated cagA gene does not affect the vacuolating cytotoxin activity of Helicobacter pylori. Infect Immun 62:2609-2613.

Tummuru MKR, Sharma SA, and Blaser MJ (1995). Helicobacter pylori picB, a homolog of the Bordetella pertussis toxin secretion protein, is required for induction of IL-8 in gastric epithelial cells. Mol Microbiol 18:867-876. 
Yamashita K, Takahashi A, Kobayashi S, Hirata H, Mesner PW Jr, Kaufmann SH, Yonehara S, Yamamoto K, Uchiyama $T$, and Sasada M (1999). Caspases mediate tumor necrosis factor- $\alpha$-induced neutrophil apoptosis and downregulation of reactive oxygen production. Blood 93:674-685.

Yamamoto C, Yoshida S, Taniguchi H, Qin MH, Miyamoto H, and Mizuguchi $Y$ (1993). Lipopolysaccharide and granulocyte colony stimulating factor delay neutrophil apoptosis and ingestion by guinea pig macrophages. Infect Immun 61: 1972-1979.
Zhang QB, Nakshabendi IM, Dawodu JB, Gemmell CG, and Russel RI (1996). Association of cytotoxin production and neutrophil activation by strains of Helicobacter pylori isolated from patients with peptic ulceration and chronic gastritis. Gut 38:841-845. 